\title{
The Structural Factors Facilitating Post-Earthquake Compromise between Contracting Parties
}

\author{
${ }^{1}$ RINEL FITLAYENI, ${ }^{2}$ MARLENI, ${ }^{3}$ IKHSAN MUHARMA PUTRA \\ ${ }^{4}$ AFRIZAL, ${ }^{5}$ INDRADDIN \\ 1,2,3 STKIP PGRI Sumatera Barat, Jl. Gunung Pangilun, Padang, Indonesia \\ 4,5 Universitas Andalas, Jl.Limau Manis, Padang \\ email: 1 rin3l_inzaghi@yahoo.co.id, 2 i_I3n@yahoo.co.id, 3 ikhsan@stkip-pgri-sumbar.ac.id \\ 4 afrizal_2002au@yahoo.com, 5 indrazainudin@yahoo.com
}

\begin{abstract}
The earthquake on September 30, 2009 occurred in West Sumatra had caused great loses and damages in several cities, including the central market known as Pasar Raya in Padang City. This condition had led to various malfunctions and local communities were unable to meet post-disaster needs. The government as the authority was not fully in line with local needs that caused the occurrence of several conflicts of interest between the Government and the traders of Pasar Raya. This research is applying the qualitative approach with descriptive types. The informants are selected through purposive sampling technique consisting of traders and the government of Padang City. The data collection techniques are in-depth interviews, document studies, and focus group discussions (FGD). The study results show that the conflicts were no longer took place openly due to the compromise among parties involved with points as follows: (a) the involvement of third parties to resolve the conflict; (b) personal approach to the traders; (c) resolving conflicts through non-litigation by the government.
\end{abstract}

Keywords: Conflict, Compromise, Contracting Parties

\section{Introduction}

Historically, the polemic of Pasar Raya Padang has started 10 years ago. The conflict began with the demolition of Andalas Bus Station and the Goan Hoat Bus Station (stations for angkot/public car, intercity, and interprovince bus) that rebuilt into a shopping center of Sentral Pasar Raya (SPR) Padang. The construction caused various problems, ranging from public transportation which "ngetem" at random spots, irregular merchant kiosk, and angkot went straight to the market without stopping at the angkot station first. This was getting worse after the big earthquake in 2009 (Minangkabaunews 2012)

The September 30th, 2009 earthquake that occurred in West Sumatra had caused wounded and losses. One of the impacts of the earthquake was the massive damages befell Pasar Raya Padang building, especially the Pasar Inpres 1. The damages have disrupted economic activities of trading between the merchants and the buyers in the market.
Such situation required special concern from various parties, especially from Padang City Government.

The government's response of action began with the construction of emergency kiosks during the emergency response period, but there was no socialization regarding the kiosks' construction. The construction of emergency kiosk turned out to exceed the capacity of the needs for disaster relocation (Elvawati, Rinel, Marleni, Afrizal, \& Indraddin, 2015: 34). Basically, the handling of market revitalization must be subjected to the applicable laws and regulations, specifically Law Number 24 of 2007 concerning Disaster Management, Government Regulation Number 21 of 2008, Government Regulation Number 22 of 2008, and other disaster legislation both in the planning process and implementation of rehabilitation reconstruction. However, the policies conducted by the government required both the government and the stakeholders' involvement in various stages 
of planning, implementation, monitoring, and evaluation (Seltzer and Mahmaudi 2013). In addition, the community members can also become an integral part of the governance process in designing and implementing the policy (Eshuis and Braun 2014).

The rehabilitation of Pasar Inpres building of Pasar Raya Padang cannot be separated from the presence of merchant civil rights in Pasar Inpres building in accordance with the agreement between the Padang City Government and the traders. The process of rehabilitation reconstruction also cannot negate the civil rights of traders as victims of the earthquake (Zusmelia and Firdaus 2016). Therefore, to avoid that, rights, the process of rehabilitation reconstruction must involve traders as the most impacted party of the earthquake disaster.

The policy of Padang City Government to forcibly fencing Pasar Inpres I, II, III, and IV of Pasar Raya Padang buildings by involving members of TNI (Indonesian National Armed Forces), Polri (Indonesian National Police), Satpol PP (Civil Service Police Unit), and Regional Police Mobile Brigade of West Sumatra that removed the traders' of earthquake victims e was unjustifiable. This is one form of human rights violation. In addition, the fences built on August 31st, 2011 that coincided the $1^{\text {st }}$ of Shawwal $1432 \mathrm{H}$, had hurt the feelings of Muslims community who were celebrating the first day of the Eid ulFitr after a whole month of fasting. Padang City Government in early August 2011 was committed to solve the problem regarding the rehabilitation and reconstruction of Pasar Raya Padang through a process of deliberation with the traders of the earthquake victims. However, the incident on August 31 $1^{\text {st }}, 2011$ apparently was not resolved consistently by Padang City Government. Also, the National Commission of Human Right as the mediator presented on June 19, 2011, to mediate the reconciliation between the traders and Padang City government (Elvawati et al. 2015).

The Padang City Government sought a place of relocation for traders who impacted from the collapse of the buildings in Pasar Raya Padang. The solution was by building the emergency stalls along Sandang Pangan and Pasar Baru streets. However, the emergency stalls were blocking the kiosks of traders who were not affected by the earthquake; they were offended and could not take it (Elvawati et al. 2015).

As a result, those traders demanded
Padang City Government to dismantle the emergency stalls that causing their decreasing revenues and lack of visitors. These demands were conducted by traders through demonstrations. Dozens of largescale demonstrations of Pasar Raya traders joined Padang City Residents Forum (Forum Warga Kota - FWK Padang) towards the DPRD (regional house of representatives) building. They asked for the city representatives to fulfill their demand: Padang City Government must dismantle the emergency stalls on the street. In the other hand, the Government insisted on maintaining the emergency stalls because they cost billions of rupiahs of funds (Elvawati et al. 2015). The conflict between the city government and the traders had been going on for five years (2009-2014), but there was no agreement for both parties. Even though those who have a role in the conflict have been identified: the contracting parties between traders and Padang City government and those who act as mediators, e.g. PBHI (Indonesian Legal Aid and Human Rights Association), National Committee of Human Right, and those acting as the third parties workers to find common ground in conflict resolution efforts (Putra et al. 2017).

Basically, the conflicts occur between the city government and the traders are open conflicts (Afrizal 2015). Therefore, the conflict outside the judiciary is effective to end the conflict of interest between the parties: the government and traders. As the result of the absence of agreement between the City Government and traders related to Pasar Raya (Central Market of Padang City) matter, the proliferation of modern markets (e.g. mini market, mall, supermarket) and the emergence of shadow market (along the main road) had resulted in the disorganized of urban planning, the decreasing income of Pasar Raya traders, and the change of consumers' preferences who like modern markets more than traditional ones. This situation has threatened the persistence of traditional markets even though traditional markets are the benchmark in improving people's welfare. Traditional markets must be maintained because they are not just a place of transaction between sellers and buyers but also as a social institution that maintains the social structure of society, especially the economic structure of the middle to lower classes (Putra et al. 2017).

In 2014 there was a significant change through compromise. This compromise contributes to the decreasing of conflict 
pressure in Pasar Raya after the earthquake. It was also the beginning of a potential meeting point for the contracted groups. Consequently, in 2015 until 2017, Pasar Raya was rebuilt by using APBD (regional budget) and APBN (state budget) funds. Based on the problems explained above, the research question for this study is: What are the structural factors that facilitate the compromise between the Padang City Government and Pasar Raya traders after the 2009 earthquake?

Tensions that occur in social structures generally consist of two forms: symmetrical conflict and asymmetrical conflict. Asymmetric conflict refers to conflicts occur in the social structure of traders and the government, while symmetrical conflict refers to conflicts occur in groups that are equal on their social structure related to the conflicts in principle of mutual symbiosis, specifically on the conflict of when will the market be revitalized and reconstructed after the 2009 earthquake. Various efforts have been made by various parties in resolving the conflicts between traders and the government but did not have significant results.

The government as an institution is certainly related to the state rules structure where the development policies must go through several stages, i.e. participatory, technocratic, and political stages. Negotiation between traders and the government is only in the participatory, to realize a plan that accommodates the interests of traders which still face obstacles in technocratic and political planning. This challenge could be related to legislation including the post-disaster reconstruction rules governed by Law No. 24 of 2007. The next obstacle is a political atmosphere which also affects the realization of the formation of traders and government (Putra et al. 2017).

There are several relevant studies related to Pasar Raya, including the research on the market conflicts by Ariesta (2014) entitled the Role of Women in the Conflict Resolution Process (Case Study of Pasar Raya Padang Rehabilitation and Reconstruction Resolution Process). The results of the study described the gap of women's role in the context of matrilineal system of Minangkabau culture in the conflict resolution process of rehabilitation and reconstruction of Pasar Raya Padang. This gap stated that women are expected to play an active role in each conflict resolution process, but in reality they only take small role. Collective action was taken by women as a role towards the conflict resolution process actually brings women as the victims of the violence. However, when the formal conflict resolution process is carried out through negotiations, women no longer play the role and follow the process. The meaning of the Matrilineal cultural system which is juxtaposed with the patriarchal political structure in Minangkabau culture about the primacy of men as representatives of public affairs and leaders of an organization is applied by the parties involved, so that it becomes an obstacle for women's role in this conflict resolution process (Ariesta 2014).

In addition, Firdaus (2014) also examined the conflict of Pasar Raya Padang. His results research found that the protests conducted by the market traders against the government were caused by several events, including losses suffered by traders due to the construction of emergency kiosks, and the development planning in the Inpres market I, II, III and IV which was not in accordance with the needs of traders (Firdaus 2014). Suryanto (2011) sees a different side of the post-earthquake case of Pasar Raya Padang. by putting more emphasis on the strategy conducted by FWK in fighting for the interests of Padang City policy. There are number of strategies conducted including formal strategies, demonstration, and violence strategies. By keep fighting for their interests, the traders successfully made the DPRD of Padang City granted their demands through the formation of a problem solving team and the acceleration of the rebuilding of Pasar Raya Padang (Suryanto 2011).

Research conducted by Rinel Fitlayeni (2015), et al. entitled Traditional Market Persistence Faced Competition with the Modern Market (Case Study in Padang Barat District showed that various strategies were carried out by traditional market traders to survive. Based on the results, it can be concluded that the persistence of traditional markets in facing the competition with the modern market is seen from (1) the price formation process; (2) traditional market systems/cultures; (3) micro-level social networks, and (4) market regulation. While the strategies used by the traders in dealing with modern markets include (1) using online media; (2) maintaining the quality of merchandise; (3) promoting merchandise outside the traditional market location, and (4) setting the lower prices (Fitlayeni, Marleni, and Elvawati 2015). 


\section{Research Methodology}

This research was conducted with a qualitative approach. Qualitative research is research that reveals the phenomenon of what is experienced by the subject of research (Moleong 2013). The type of this research is descriptive because researchers seek for the existing phenomena. Descriptive research is a fact-finding with the right interpretation. It studies the problems in society and certain situations including the relationship of activities, attitudes of views, the ongoing processes, and the influence of a phenomenon. This study examines asymmetric conflict resolution (conflict resolution case study of Pasar Raya Padang post-earthquake). The research informants are determined intentionally (meaningful), meaning that they are sought based on certain criteria set by the researcher (Afrizal 2008). The criteria for the informant in this study are the actors involved in the of Pasar Raya Kota Padang consisting of traders and the Market Service.

Data of this study is collected through collecting documents (writings), such as news in the media, minutes of meetings, and reports related to the conflict that occurred. Data collection is also done through observations by viewing at the approaches taken by the government to the traders. Besides the observations, in-depth interviews are also conducted. namely an unstructured interview between the interviewer and the informant that is done repeatedly with different questions and classifies previously obtained information (Afrizal 2008). In this case, the researcher still uses the interview guidelines so that the researcher does not leave the desired subject matter in accordance with the research objectives. When conducting research, the researcher informs the informants about the usefulness of the study. The interview process is conducted with the government by visiting actors who are directly related to the research problems in their spare time. The same thing applies to the traders, in which the interview is carried out when they do not serve too many buyers. It is done as to not disturb the activities of traders in buying and selling transactions. The informants of this research are 24 people from the DPRD of Padang City members, representatives of Padang City Government, representatives of PBHI members, National Commission on Human Rights Representatives, and Representatives of traders involved in the conflict after the 2009 earthquake.
Interviews with Padang City DPRD members are carried out by fostering personal relationships with them. This personal relationship can facilitate the process of approaching informants since the formal approach with cover letters will be ineffective considering the complexity of administration at the Regional Representative Office of Padang City. Personal approach to DPRD members is able to lead competent speakers as actors who play a role in conflict resolution.

Interviews can be carried out several times with the Head of the Padang City Trade Service and secretary of the Padang City Trade Office. The Padang City Trade Office is currently separated from the industry so that the trade service at the time of the research was already more focused on managing the market, especially traditional markets in Padang.

\section{Results And Discussion}

\section{The Compromise In Order To Resolve The Asymmetrical Conflict}

Pasar Raya Padang is the largest market and traditional market center in Padang. The existence of a market as a large market has an element of interest in it. The element of interest between economic actors on the market is normal. The type of actors relationships in the market is between traders, traders and market service, and traders and transporters. Although economic actors are identical with their respective interests, it is still considered appropriate and will not damage the system that has been built before.

Pasar Raya is an asset for Padang City Government as one of the sources of regional income (Pendapatan Asli Daerah - PAD). The assets are fully managed by the Market Service, which means that all the buildings in Pasar Raya belong to Padang City Government. Traders are given space to carry out economic activations in accordance with regional regulations. The authorization includes the mechanism to purchase usufructuary rights (rights to use shops, kiosks, and stalls, such as the rental of kiosks for certain period of times), as well as the retribution mechanism collected by the Market Service as a source of regional income. As stated by Adek (plastic trader):

"ambo disiko sajak gampo, sasudah bangunan salasai, maka pedagang bisa memiliki hak pakai untuk kios. Untuk mendapatkan hak pakai kios ko, ado beberapa syarat yang ditantuan dek pemerintah : yaitu kartu kuning 
serta pedagang aktif. Untuk kartu kuning bagi pedagang yang sudah memiliki kios sebelum gampo. Sedangkan yang aktif untuk pedagang yang rajin beraktivitas di pasar raya. Hak pakai yang diberikan dalam jangka waktu 25 tahun."

I have been here since the earthquake. After the building was finished, the traders could have the right to use the kiosk. To get kiosk usage rights, there are several conditions given by the government: yellow cards and active traders. Yellow cards are for traders who already have a kiosk before the earthquake, while active traders are those who are active in the market. The right of use is are granted within 25 years.

All subsystems in the market will contribute to other subsystems; so many traders organize themselves into merchant organizations they form together. This organization has an important role as a representation of all traders in facilitating communication with various parties, especially the Padang City Government.

The market went well until one the earthquake hit on September 30, 2009, which damaged the market building. Heavy damages of Pasar Raya building must be immediately repaired by the government and the communities, in this case, traders who still have rights to the damaged shops, kiosks and stalls. However, there are some disappointments from traders and the public towards Padang City Government, in this case, the Market Service which is a representation of the City Government. The traders' disappointments were expressed in the form of protest to Padang City Government. Sztompka (2006: 235) stated that the collective movement conducted in an institution could produce the changes in society. It means that traders' collective movement is a form of protest as the disaster victims (Sztompka 2006).

There are two conflicting parties in this market conflict: the first party is the one sued and the second party is the one being sued. The first party was market traders as the victims of the September 30th 2009 earthquake, and the second party was Pasar Raya Market Service and Padang City Government. There are two different positions in the social structure of the contracting parties. Padang City Government is a governmental organization with the power and authority to run the governmental functions. This authority created an unequal power relationship where the government has an executive position, while the community is in the bottom position with barely any power. Asymmetric conflict refers to a dispute where one party is in the weak position of having no power (powerless) (powerless) (Mail, Ramsbotham, and Woodhouse 1999). The government has the power to emphasize the community, so that the community can be said to be a weak party. Padang City Government as the party with power has become the trigger of the conflict in the market.

The examples of the cases occurred are policies made and issued by Padang City Government related to the construction of Emergency Stalls on the $23^{\text {rd }}$ day after the September 30th earthquake. The construction seemed to happen all of sudden by involving the TNI Yon Zikon 13/kf, wih the contract value of 2.4 billion rupiahs. The Stalls were built in front of Pasar Inpres III which was not affected by the earthquake. The construction had 3 problems: first, the development was not socialized to the traders; second, the number of stalls exceeded the amount needed so that they built them in shape; third, the construction prevented buyers from entering the Pasar Inpres II, III and IV (Firdaus 2014). The policy implemented by Padang City Government, in principle, was based on thire power and authority without involving the traders who would use the emergency stalls. This policy was still implemented despite protests from traders.

\begin{abstract}
The government took an emergency action by building the emergency stalls for the traders to continue their economic affairs, but this is assessed by certain individuals as a wrong policy, (Jasman, Secretary of the Padang City Trade and Market Service).
\end{abstract}

The interview explained that the government, after the earthquake, continued to strive to build emergency market facilities. One of the facilities was the construction of emergency stalls. The traders protested against the construction since the stalls were not in accordance with what they desired as earthquake victims.

At the time, compromises made between traders and Padang City Government which was represented by the Padang City Market Service. Some of the compromises were facilitated by the Regional Representatives Council (DPRD) of Padang City as a party that was considered to represent the interests of the people. Facilitation and compromise efforts at the resolution process were carried out by Padang City DPRD through various meetings and investigation by individual and institutionalized DPRD members to investigate various cases occurred in the market. The city government meeting with traders which 
was facilitated by the Padang City DPRD at the Padang City DPRD Office became a useful meeting point. By the year of 2015, 2016 and 2017, the reestablishment of Pasar Raya Padang was conducted using regional and national budget.

\section{Table 1}

\section{Events in Pasar Raya Padang that Involve the DPRD}

DPRD's Involvement

1. Mediation. The first conflict was negotiated at KomnasSHAM (National Commission on Human Rights) Center involving members of the Padang City DPRD personally. DPRD members present at the time were the Chair of the Golkar Party, Democrats, Bulan Bintang Party, HANURA, PKS; and the elements of the DPRD chairman: Deputy, Faction, and the Commission.

2. Hearing and Audience continued by DPRD members as well as reports to the DPRD on KomnasHAM on November 8th, 2011, for the demands of unclear budgeting for the rebuilding of Phase III and IV of the markets. There is an important issue: the traders considered the government is not serious about the budgeting (regional and national budget) because government wants to bring the investors in.

3. The demolition of Pasar Inpres III Bagonjong case occurred on April 22nd, 2012. of. The emergency stalls were already placed in front of Matahari Department Store by Satpol PP Padang. The demolition failed because the traders force the demolishers out. The tension between two conflicted parties subsided due to the presence of the deputy chairman of the Padang City DPRD along with several DPRD members. After that, representatives of both parties met and produced a solution: the government continued to carry out the rehabilitation and reconstruction program before Eid (April 25, 2012).

4. On May 22nd, 2012, a hearing was held by DPRD with various parties regarding the budget for Pasar Raya Padang rehabilitation.

And so on.

Source: (Putra et al. 2017)

Based on data from Table 1, there are at least 4 records of formal compromises that were made through the facilitation of Padang City DPRD. The compromise that has been sought by various parties including third parties in the process of resolving real market conflicts has contributed to the step towards resolution. This compromise with formal mediation is representative. Pasar Raya traders group is represented by a group of people who are considered representations of market traders, namely the Pasar Raya Traders Association (Asosiasi Pedagang Pasar Raya - APPR).

Apart from the compromise facilitated by third parties, there is also a compromise carried out by market service managers. The market manager as the executor of Pasar Raya rehabilitation and reconstruction carried out a compromise to market traders by visiting them individually. This is indeed a very large work done by but has contributed greatly to conflict resolution of Pasar Raya Padang. Below is the market manager' statement:

We met directly with traders of-of earthquake victims, then we listed and explained that the rebuilding of the market was scattered so as to guarantee what the traders hoped would be truly done by the government, (Jasman, Trade and Market Service Secretary).

The steps taken by the market service are the key to connecting the facilitation that has been carried out together with representatives of the APPR merchant group. The Padang City Government's policy to compromise personally is a step agreed upon for the government. This step was chosen because there were many interests that had been analyzed by the government and also to prevent the protest actions of the market traders. If persuasive actions are continued with a system of groups representation, then they are also driven by other interests. To anticipate this, the compromise action is directed at a personal approach. Election of Regional Heads (PILKADA) is also very influential in the conflict resolution process. Viewing at the prolonged conflict situation, there is a transitional period of the leadership of Padang Mayor Mr. Fauzi Bahar, which in 2013 was held by the Municipal Election of Padang. This is the point where conflict resolution cannot be obtained, which impedes the completion of Pasar Raya Padang construction.

\section{The Structural Factors Facilitating Post-Earthquake Compromise Be- tween Contracting Parties}

The policy of the Padang City Government to choose persuasive steps in conflict resolution is a policy considered appropriate. Seeing several cases of conflicts that occur in traditional market development, conflicts can be widespread when the government is unable to take policy among many interests due to limited governmentowned resources (Sudarmo 2016). Policies for conflict resolution in a persuasive manner have made the resolution according to the needs of the trader or a win-win solution., The City of Padang administration decided 
that the Non-litigation step was also in line with the needs of traders at that time, as it stated below:

The steps taken to resolve this conflict are non-litigation; traders have indeed decided to choose this step, hoping to get the winwin solution. (Firdaus, Activist of PBHI West Sumatra).

Based on the interview above, it can be said that the government policy, in principle, is in line with the needs of traders, especially the steps were chosen for problem solving. Policy through the involvement of third parties in the conflict resolution process becomes a factor that contributes to facilitating a compromise. It can be seen and understood when KOMNAS HAM and Padang City DPRD facilitate meetings between conflicting parties. Compromise occurs collectively due to the existence of groups that are considered representations of both parties. However, it did not contribute much to conflict resolution, which can be seen that the conflict in 2013 until the end of 2014 showed no decrease.

The history of the conflict between traders and the government began after the earthquake in 2009. The market facilities collapsed, especially the Pasar Inpres buildings as a place that accommodated number of shops where sellers and buyers meet. The conflict peaked in 2011, 2013, and 2014. In 2015, conflict escalation began to decline along with leadership change or change of mayors in 2014. The leadership change through the regional head elections in 2014 was an important point in the history of the asymmetric conflict market resolution. There were 3 candidates for the regional head election contestation. The first candidate was Fauzi Bahar who was the incumbent Mayor of Padang, the second one was Mahyeldi who was the Deputy of Mayor, and the third was Desri Ayunda who was a new political contestant in Padang. Of the three participants in this regional head election, Mahyeldi got the most votes. The change of leaders in 2014 has contributed to reducing the pressure of conflict in the market.

The decrease in conflict pressure was seen to be lower; joint activities to demand the construction of Pasar Raya Padang still remained but not destructive. After the leadership change, traders actually have great hopes for the reconstruction of the market in accordance with their needs. Thus, The change of the Mayor created different atmosphere for the conflict. The new leaders used a persuasive approach to traders. It means the government accommodated the voice or opinions of traders if they have problems. Traders can contact the government directly. It turned out that a different approach make changes in the conflict process.

\section{Description of conflict Escalation level over the years}

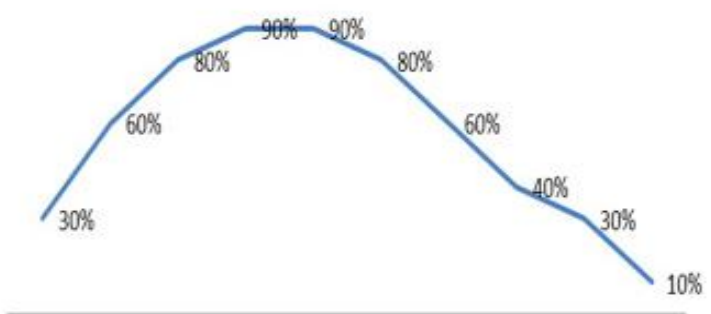

$\begin{array}{llllllllll}2009 & 2010 & 2011 & 2012 & 2013 & 2014 & 2015 & 2016 & 2017 & 2018\end{array}$

Figure 1. Description of Conflict Escalation Level Over the Years

Based on Figure 1, it can be seen that the peak of the conflict occurred in 2013 and 2014. If it was associated with political phenomena, indeed it can be concluded that there was political interference in postdisaster conflicts in the market. This was also confirmed by Jasman (a secretary of market service) who stated that:

\begin{abstract}
"Admittedly, the possibility of resistance that arose in the construction of the market was a political content in the approach of regional head elections agenda. It can be seen when each time market service wants to discuss with traders, the government's proposal or market service has already been rejected before it is negotiated at the traders level." (Jasman, Juli 2018).
\end{abstract}

The change of Padang City leadership from Fauzi Bahar to Mahyeldi had an effect on approaches used by the Padang City Government to achieve conflict resolution. Policies that were built after new leadership have begun to accommodate the demands of traders. Problems of traders can be conveyed directly to the Padang City Government. Compromise carried out by the government is a benchmark in dealing with conflicts. In line with that, Gerstle stated that conflict can be resolved by taking advantage of opportunities, one of which is to see the economic conditions in the market (Fitlayeni et al. 2019).

The demands of traders include financing the market reconstruction by APBD of Padang City with the assistance of West Sumatra Province's regional budget. The traders' resistance was starting to fade 
when the market construction began. At the end of 2017, the highway market building has been completed and started to operate at the beginning of 2018.. The placement of traders was adjusted to the agreement between traders and the government, in this case, the market service or trade service of Padang City. The placement is done through a plot system to avoid jealousy between traders.

The next policy that is structurally considered to facilitate compromise is the policy of the Padang City Government to choose the steps to approach the earthquake victims personally or what is the Market Service referred to as sustainable persuasion. This method is applied to promote market development to traders to minimize issues that damage the situation on the market. Market officials made a personal approach to the traders to reduce resistance due to the relatively long development process. Padang City Government conducts market rehabilitation on all sides including the market spatial layout.

\section{Conclusions}

The conflict occurred at Pasar Raya Padang after the 2009 earthquake was one form of Asymmetric conflict. The conflicting parties are basically in unbalanced situation of structure and power: the government as a party with power is in conflict with traders who do not have power in the structure.

The existing conflict resolution is a compromise made by various parties facilitated by third parties. There are several factors facilitated the compromise, especially the structural factors of the government that have made the compromise work. The structural factors are; the government's policy to choose the steps of non-litigation solutions, the government policies to be facilitated by third parties, and the government policies to compromise the traders personally.

\section{References}

Afrizal. (2008). Pengantar Metode Penelitian Kualitatif:Dari Penelitian Sampai Penulisan Laporan. Unand: Laboratorium Sosiologi Fisip Unand.

Afrizal, A. (2015). "Third-Party Intervention in Terminating Oil Palm Plantation Conflicts in Indonesia: A Structural Analysis." Journal of Social Issues in Southeast Asia 30(1):141-72.

Ariesta, I.(2014). "Peran Perempuan Dalam Resolusi Konflik Rehabilitasi Dan Rekonstruksi Pasar Raya Padang." Jurnal
Ilmu Sosial Mamangan 1(2):41-51.

Elvawati, Fitlayeni Rinel, Marleni, Afrizal, and Indraddin. (2015). Model Resolusi Konflik Dalam Institusi Lokal, Studi Kasus Pasar Raya Padang Pasca Gempa 2009. Padang.

Eshuis, J. Klijin E. and E. Braun. (2014). "Place Marketing And Citizen Participation; Branding as Strategy to Address the Emotional Dimention of Policy Making." International Review Od Administrative Sciences 1(80):151-71.

Firdaus. (2014). "Protes Korban Bencana; Studi Konflik Penanggulangan Bencana Di Pasar Raya Kota Padang." Jurnal IImu Sosial Mamangan 1(2):27-39.

Fitlayeni, Rinel, Marleni, and Elvawati. (2015). "Strategi Organisasi Informal Menjaga Persistensi Pasar Tradisional Di Kecamatan Padang Barat." Jurnal Sosial Dan Pembangunan MIMBAR 31(1):61-70.

Fitlayeni, Rinel, Ikhsan Muharma Putra, Marleni Marleni, Afrizal Afrizal, and Indraddin Indraddin. (2019). "Persuasive Sustainable Models for Conflict Resolution Post-Earthquake." Atlantis Press 307(SoRes 2018):458-61.

Mail, Hugh, Oliver Ramsbotham, and Tom Woodhouse. (1999). Contemporary Conflict Resolution. Malden: Polity Press.

Minangkabaunews. (2012). "Pasca Gempa 30/S, PR Rehab Rekon Masih Menggatung." Minangkabaunews.Com, September, 009.

Moleong, L. (2013). Metode Penelitian Kualitatif. Bandung: Remaja Rasda Karya.

Putra, Ikhsan Muharma, Fitlayeni Rinel, Marleni Marleni, Afrizal Afrizal, and Indraddin Indraddin. (2017). Model Resolusi Konflik Asimetris (Studi Kasus Resolusi Konflik Pasar Raya Pasca Gempa Tahun 2009). Padang.

Seltzer, E. and D. Mahmaudi. (2013). "Citizen Participation, Open Inovation and Crowdsourcing: Challanges and Opportunities for Planning." Journal of Planing Literature 28(1):3-18.

Sudarmo. (2016). "The Implications of Taditional Market Development for Governance of Conflic: An Experience of Klewer Market of Surakarta, Indonesia." Jurnal of Government \& Politics Volume 7(4):619-39.

Suryanto. (2011). "Strategi Kelompok Kepentingan Memperjuangkan Kepentingannya Dalam Konflik Forum Warga Kota (FWK) Terhadap Kebijakan Pemerintah Kota Padang." Andalas.

Sztompka, P. (2006). Sosiologi Perubahan Sosial. 1st ed. Jakarta: Prenada.

Zusmelia, Z and Firdaus, F. (2016). "The Traditional Economic Space Management System in Pasar Raya Padang Market, West Sumatera after the Earthquake 2009." Jurnal Kebijakan Dan Administrasi Publik 20(2): 24-36. 